\title{
Chapter 4. Borneo as a Cross-Roads for Comparative Austronesian Linguistics
}

\section{K. Alexander Adelaar}

The autochthonous languages of Borneo have been divided into ten separate subgroups (Hudson 1978). This paper discusses four subgroups on which the author has done research.

The Southeast Barito subgroup includes Malagasy. This language underwent considerable influence from Malay and Javanese. Malay influence appears to have lasted until after the introduction of Islam in Southeast Asia, and there are also some indications that the Arabic script was introduced to Madagascar by Indonesians (possibly Javanese). The author puts forth the hypothesis that the Malagasy, rather than having sailed to Madagascar of their own accord, may have been transported there (as subordinates) by Malays.

The Malayic subgroup includes Iban and Malay. The diversity and relative archaism of the Malayic languages spoken in West Borneo suggest that the Malayic homeland may have been in this area.

The Tamanic languages are phonologically, morphosyntactically and lexically close enough to the South Sulawesi languages to form a subgroup with them. They have some striking phonological developments in common with Buginese, with which they seem to form a separate branch within the South Sulawesi language group.

The Land Dayak languages have a few striking lexical and phonological similarities in common with Aslian languages. This suggests that Land Dayak originated as the result of a language shift from Aslian to Austronesian, or that both Land Dayak and Aslian have in common a substratum from an unknown third language.

\section{Introduction}

If one thing has become clear in the last one and a half centuries, it is that Borneo, in spite of some shallow appearances to the contrary, represents an amalgamation of ethnic groups with often very different origins. Where Hardeland in the mid19th century (Hardeland 1858, 1859) still thought it suitable to call the language of his dictionary and grammatical sketch "Dayak", it now appears to be merely one of the Northwest Barito languages, which in turn form a branch of the West Barito grouping in the southern part of Borneo. According to Hudson (1978), 
the West Barito language group is but one of the ten linguistic subgroups to which the autochthonous languages of Borneo belong.
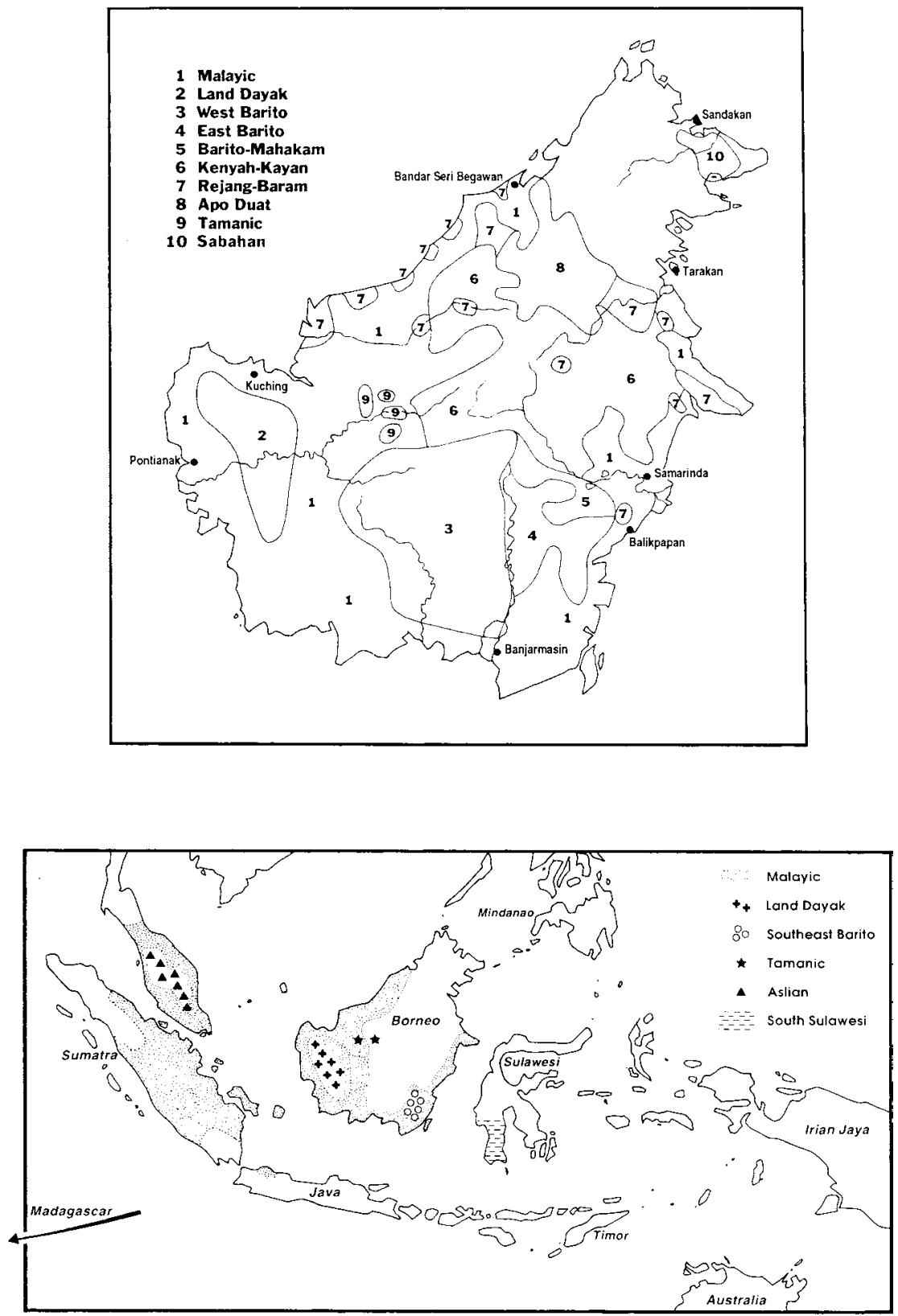

Map 1: Borneo language subgroups and their relationships to exo-Bornean subgroups. 
Hudson classified the Bornean languages into seven endo-Bornean groups (Land Dayak, Rejang-Baram, Kenyah-Kayan, Apo Duat, West Barito, Barito-Mahakam and East Barito ${ }^{1}$ ) and three exo-Bornean groups (viz. Malayic Dayak, Tamanic and Sabahan ${ }^{2}$ (see Map 1). According to Hudson, these ten groups are at least as different from each other as they are from any other (non-Bornean) Malayo-Polynesian linguistic subgroup, and the exo-Bornean groups are each closely related to some non-Bornean languages. Malayic Dayak languages are part of the Malayic sub-family (including, among others, Malay, Minangkabau and Banjarese), Tamanic languages are most closely related to South Sulawesi languages, and Sabahan languages subgroup with the Philippine languages (Hudson 1978). Apart from the autochthonous languages, there are also several Malayic, Bajau and Chinese languages which have a long history in Borneo: they are mainly spoken in coastal areas and in towns. ${ }^{3}$

Although preliminary, Hudson's classification is more comprehensive and scientific than previous classifications of Bornean languages.

Through my linguistic research during the last five years I have been able to make further explorations into the history of four of Hudson's subgroups, viz. East Barito, Malayic Dayak, Tamanic and Land Dayak. I have also been doing research on the influence of Malay and other Indonesian languages on Malagasy. During four short field trips to West Kalimantan I have collected a large corpus of data on Salako (a Malayic Dayak language) and on Embaloh (a Tamanic language), and I have collected basic wordlists for a large number of Land Dayak languages. ${ }^{4}$ These and other linguistic data allow us to make some inferences about the origin and spread of the speakers of the languages involved. The following paragraphs, which are organized according to linguistic subgroup, detail these inferences.

Many of the arguments that I present in this paper have already been treated elsewhere, and the reader is referred to the Adelaar references (1989, 1991a, 1991b, 1994 and in press) for a fuller account of these arguments and for extensive bibliographical references. In only one instance do I put forward a viewpoint that I have not discussed previously; this concerns suggested similarities between Land Dayak languages and Central Orang Asli languages.

\section{East Barito: Who Were the Malayo-Polynesian Migrants to Madagascar?}

Dahl $(1951,1977)$ showed that Malagasy, the Austronesian language spoken as a number of dialects by almost all inhabitants of Madagascar, belongs to the Southeast Barito subgroup, ${ }^{5}$ the other members of which (Maanyan, Samihim, Dusun Malang, Dusun Witu, Dusun Deyah and Paku) are spoken in the southeastern part of Borneo. Dahl observed that Malagasy has a relatively small number of Sanskrit loanwords in comparison to the large numbers in some 
Indonesian languages. According to him this indicated that the East Barito migrants to Madagascar must have left their homeland only just after Indian influence had begun to affect the Indonesian languages and cultures. Considering the fact that Indian linguistic influence in Indonesia can be traced to a date as far back as the fifth century AD, Dahl concluded that the migration must have taken place at this time or slightly after. He does not explicitly consider the possibility of influence from other Austronesian languages.

The first extensive studies of such influence (Adelaar 1989, 1991a and in press) show that there are many Malay loanwords in Malagasy, and that there are also a number of loanwords from Javanese. Malay and Javanese were also the vehicular languages for the Sanskrit vocabulary in Malagasy. Thus, none of the Sanskrit loanwords support the assumption of direct Indian influence on the Malagasy language. This has an important consequence for Dahl's date of the migration to Madagascar: as all Sanskrit influence in Malagasy was channelled through Malay and Javanese, we should postdate the migration to the first Malay and Javanese influence on Malagasy, rather than to the first Indian influence in Indonesia. It is as yet not possible to date the first Malay and Javanese influence on Malagasy, although it is likely that it happened at least two centuries later than the fifth century AD. The borrowed material also gives us information on the nature of the influence of Malays and Javanese on the migrating East Barito speakers, influence that must have begun some time before the migration, and that must have lasted until a considerable time afterwards.

Generally speaking, the Malay and Javanese loanwords belong to all sorts of semantic domains. But Malay loanwords are particularly well represented in the domain of maritime life and navigation, as can be seen in the following examples:

trozona 'whale' < Malay duyu $\eta$ 'sea cow'

horita 'octopus' < Malay gurita 'id.'

fano 'turtle' < Malay panu 'id.'

hara 'mother-of-pearl' < Malay karah 'patchy in colouring (of tortoise-shell)'

fanohara (dialectal) 'turtle with a particular kind of shell' < Malay panu karah 'tortoise-shell turtle, Chelonia imbricata'

vontana (dialectal) 'kind of fish' < Malay ikan buntal 'box-fish, globe-fish or sea-porcupine'

tona 'k.o. large nocturnal snake; enormous eel' < Malay tuna 'name of a mud-snake or eel with yellowish body'

lamboara 'a species of fish' < Malay lambuara, Old Javanese lambwara, lambora 'a giant fish (possibly a whale)' 
vidy (dialectal) 'k.o. small fish' < Malay ikan bilis 'anchovy, Makassar redfish; small fish, esp. Stolephorus spp.'

hoala (dialectal) 'bay, inlet' < Malay kuala 'river mouth'

rivotra 'wind, storm' < Malay (ay in) ribut 'stormwind'

tanjona 'cape, promontory' < Malay ta juy 'id.'

an/drefana 'West' < Malay dopan '(in) front'

valaha (dialectal) 'East' < Malay b lakay 'back; space behind'

a/varatra 'North' < Malay barat 'West'

sagary 'a northeast wind' < Malay or Javanese səgara 'sea' (< Sanskrit)

varatraza (dialectal) 'south wind' < Malay barat daya 'Southwest'

tsimilotru (dialectal) 'north wind' < Malay timur laut 'Northeast'

harana 'coral-reef, coral-rock' < Malay kara $\eta$ 'id.'

sambo 'boat, vessel' < Old Malay sāmvaw 'vessel' (originally from Khmer)

nosy 'island' < Javanese nusa (with variant forms nusya, nuswa, nu ysa) 'id.'

Terms like varatraza and tsimilotru must have been borrowed from a form of Sumatran Malay, since the Malay directional terms barat daya and timur laut were originally South Sumatran developments.

Loanwords are also often found in the domain of plant names, animal names and in metallurgic terminology. Compare the following terms which are related to metallurgy:

harafesina 'rust' < Malay karat bosi 'id.'

firaka 'tin, lead' < Malay perak 'silver'

landaizana 'anvil' < Malay landasan 'id.'

Higher numerals and calendrical terms are originally Malay and/or Javanese adaptations of Sanskrit terms. Sanskrit loanwords came into Malagasy via Malay or Javanese, as their shape or meaning often betray. Compare the following instances:

sisa 'remainder, rest' < Malay sisa 'id.' < Sanskrit çe șa 'id.'

asotry (dialectal) 'Winter' < (Old) Javanese asuji 'September-October' < Sanskrit a çvayuja 'id.'

tantara 'story, legend' < Malay tantra (obsolete), Old Javanese tantra 'id.' < Sanskrit tantra- 'chapter of a scientific book, doctrine, theory'

hetsy '100,000' < Malay koti, Javanese sa-koți 'id.' (both obsolete) < Sanskrit koți 'ten million' 
That these terms were borrowed via Malay and Javanese is supported by the fact that, of all Sanskrit loanwords in Malagasy (at least 35 in total), there is only one word that is not also found in Malay or Javanese. ${ }^{6}$

A large part of the vocabulary for body-parts in Malagasy was originally Malay or Javanese:

hihy 'gums', (dialectically) 'teeth' < Malay gigi 'id.'

voto 'penis' < Malay butuh 'id.'

fify 'cheek' < Malay pipi 'id.'

molotra 'lip' < Malay mulut 'mouth'

voavitsy 'calf of leg' < Malay buah botis 'id.'

sofina 'outer ear' < Malay cupi $\eta$ 'lobe (usually earlobe)'

tratra 'chest' < Malay dada 'id.'

haranka (dialectal) 'chest' < Malay $k$ rajka 'skeleton'

valahana 'loins' < Malay b lakay 'back; space behind'

lamosina, (dialectically) lambosy 'back' < Old Javanese lamu ysir 'back; piece (of meat) from the back' (cf. also Minangkabau Malay lambosi a 'shoulder of a $\left.\operatorname{cow}^{\prime}\right)$

The Malagasy have a pre-colonial writing system which is an adapted form of the Arabic script. The writing system is called Sorabe, which derives from soratra 'writing' ${ }^{7}$ and be 'big'. The name Sorabe and some of the adaptations in its system indicate that the concept of writing, and possibly also the actual writing system of the Malagasy, were introduced by Southeast Asians, and probably Javanese. One rather idiosyncratic adaptation is also found in Pegon, the Javanese version of the Arabic script. Sorabe uses Arabic dāl and ta respectively, both with a subscript dot, for $d$ and $t$ : these are the same symbols as used in Pegon for the Javanese retroflex $d$ and $t$ respectively. Javanese speakers make a contrast between a dental series $d$ and $t$ and a retroflex series $d$ and $t$, and they perceive the alveolar consonants from other languages as retroflex consonants. Their perception of alveolars in foreign languages as retroflexes may have induced them to interpret Malagasy $d$ and $t$ as retroflexes, and to write these retroflexes as dal and ta but with a subscript dot, as in the Pegon script. This practice was taken over by the Malagasy, if it can be assumed that they learnt the Arabic script from the Javanese.

If they did, this probably happened during continued contacts after the period of migration. There is some lexical evidence that the Malagasy were still in contact with Malays or Javanese after the latter came under the influence of Islam. Compare the Antaimoro Malagasy sombidy 'to slaughter'. This term derives 
from Malay sambaleh or sambalih 'slaughter according to Muslim ritual', which in turn derives from Arabic b'ismi'llahi [besmelæh] 'in the Name of God', an utterance made at slaughtering an animal according to Muslim law.

An important question now is how to interpret the linguistic data, and how to integrate them in a theory which also takes into account archaeological, historical and anthropological findings. The problem is that the linguistic data do not seem to correlate with data from these other disciplines, and as a consequence some non-linguists are reluctant to accept the linguistic evidence. Quite apart from the fact that there is considerable regional diversity in the cultures of Madagascar themselves, many manifestations of Malagasy spiritual and material culture cannot unequivocally be linked up with the spiritual and material culture of the Dayaks of the Southeast Barito area. Some of the Malagasy are wet rice cultivators, while Dayaks are as a rule dry rice cultivators. Some Malagasy use outrigger canoes, whereas Southeast Barito Dayaks never do. The Malagasy migration to East Africa presupposes navigational skills which are found with some Indonesian peoples but which can hardly be attributed to Dayaks, who, as we know them today, are as a rule forest dwellers. Some of the Malagasy musical instruments are allegedly very similar to musical instruments found in Sulawesi, and Malagasy funeral cults are reminiscent of the Toraja funeral cults. Certain aspects of administration and statecraft of the Merina are in striking agreement with those of the Indianized Malays and Javanese, and rather unlike what has been described for the Maanyans in the Southeast Barito area. Some see a resemblance between the metallurgic practices of the Malagasy and those of the inhabitants of Nias.

The confusion caused by these data is partly due to the fact that some scholars fail to put the mass of evidence into its right perspective, which can only be done by keeping a rigorous distinction between (a) what is general Austronesian, (b) what is due to Indian influence in Southeast Asia, and (c) what is exclusively found in Madagascar and in one of the other Austronesian societies. Similarities which turn out to be general Austronesian are neither critical for a subgrouping argument nor for a cultural contact argument. In the Malagasy context (and in the context of most other regional Indonesian cultures), similarities which are the result of Indian influence only show us, in an indirect way, the extent of influence which the Indianized Malays and Javanese exerted on the Malagasy. What is relevant for a search into the Southeast Asian origins of the Malagasy people is a large concentration of similarities found in Madagascar and in one other Austronesian society in particular. Then again, these similarities are only relevant insofar as they do not turn out to be Proto-Austronesian retentions which were lost everywhere else in the Austronesian world. These similarities may point to a common inheritance or to cultural contact. Apart from (a), (b) 
and (c), other similarities due to chance, or due to interethnic contacts in Indonesia before the Malagasy migration, may also have to be distinguished.

But even with a rigorous distinction between (a), (b) and (c), we are still left with a number of seemingly contradictory factors. For instance, what brought some forest dwelling Dayaks to make one of the most spectacular migrations in history, and why do the Malagasy cultural data not support the linguistic evidence? These factors can be accounted for if we adopt the hypothesis that the Southeast Barito migrants did not undertake the crossing of the Indian Ocean themselves in order to colonize Madagascar, but that they were brought there as subordinates (slaves, ship crew, labourers) by Malays. Malays were seafarers, and they sailed the maritime routes all over Southeast Asia and along the Indian Ocean coast. They also took slaves from other parts of Southeast Asia with them, and it is quite likely that they took subordinates along on their trips to the Indian Ocean. Some of these subordinates may have been South Barito speakers.

If some of these subordinates were left behind in Madagascar, and if the Southeast Barito speakers among them formed a majority or a nuclear group (the first group to be left behind and to form a society), their language would have constituted the core element of what later became Malagasy. In this way their language may also have absorbed elements of languages of other subordinated Southeast Asians. ${ }^{8}$ A certain amount of cultural mixture may have taken place through contact with subordinates from elsewhere in Indonesia, although the language of the resulting mixed community remained predominantly Southeast Barito. The members of this community would initially have lived in a state of diglossia with their leaders, who spoke Malay (and Javanese?). At some point in time, Malay was superseded by Malagasy, but its earlier prestigious position is still witnessed by the great impact it had on the Malagasy lexicon. Compare, for instance, the Malay and Javanese influence on terms for body-parts, a semantic domain which is susceptible to reflexification with prestige vocabulary. In some cases these two languages also affected the morphology of Malagasy. ${ }^{9}$

A development as outlined above is not unlike the history of English after the Norman invasion, where French became the language of prestige for some time and heavily affected the English lexicon, and in some cases even morphology, before it fell into disuse. In the case of English, however, this development coincided with a far-reaching simplification of the original Anglo-Saxon grammar, whereas Malagasy morphology is very conservative. It probably has the same measure of complexity as Proto-Southeast Barito had originally, a complexity which was lost in the other Southeast Barito languages. 


\section{Malayic Dayak: Arguments for a Bornean Homeland of Malay}

Hudson (1970) should be credited for identifying and defining the Malayic Dayak subgroup. Previous scholars were not aware of this subgroup and classified the Malayic Dayak languages either with the Malay dialects spoken by Muslims on the Borneo coast or with the Land Dayak languages. In this way they classified Iban as a Malay dialect, and Salako as a Land Dayak dialect with strong Malay influence. Kendayan Dayak was seemingly also considered as a strongly Malayicized variety of Land Dayak (cf. Cense and Uhlenbeck 1958). Hudson, however, calls Iban, Kendayan, Salako and other closely-related Dayak languages 'Malayic Dayak', and he classifies them together with Malay and other Malay-like languages ${ }^{10}$ into the 'Malayic' linguistic group. His term 'Malayic Dayak' is meant to distinguish Malayic languages spoken by non-Muslims in Borneo from other Malayic languages. It is therefore not a linguistic term sensu stricto, but the term is relevant in Bornean linguistics insofar as it distinguishes autochthonous Malayic languages from Malayic languages which are the result of later migrations of (Muslim) Malays into Borneo (e.g. Banjarese, Sarawak Malay, Brunei Malay and other Malay varieties spoken by Muslims).

Hudson's classification of Iban, Salako, Kendayan and related languages into a single subgroup distinct from Land Dayak is very important, as it emphasizes the fact that these languages are relatives of Malay which have undergone a separate development, and not hybrid forms of Malay with a strong non-Malay substratum or adstratum. In other words, these languages are highly relevant for the history of Malay and for the reconstruction of Proto-Malayic. For instance, Salako and Kendayan retained the causative prefix maka- and the subjunctive suffix -à? (Kendayan -a?). maka- and -à?/-a? reflect Proto-Malayo Polynesian (henceforth PMP) * maka-, a causative prefix, and $\mathrm{PMP}^{*}{ }^{*} a$, a subjunctive marker respectively. Both were lost in other Malayic languages.

Examples:

Salako rehetn 'light' vs maka-rehetn 'make lighter (a punishment)' Kendayan lalu 'past, further', molot 'mouth' vs makalalu molot 'keep one's promise, act according to what one has said'

Salako mare? 'to give' vs mare-a? 'in order to give, so as to give'

Salako nabàky 'chop off' vs nabaky-à? 'in order to chop off, intending to chop off $^{\prime}$

Compare also the following Malayic Dayak words (from Iban and Salako) which were retained from PMP, and which were usually lost in other Malayic languages:

Iban $u i$, Salako ui? 'rattan' < PMP *qu a y (Malay rotan); 
Iban, Salako asu? 'dog' < PMP *asu (Malay anji g);

Iban tama?, Salako tamà? 'go inside' < PMP *tama? (Malay masuk);

Salako tau, talu 'three' < PMP *t o lu (Malay, Iban tiga);

Iban mua, Salako muhà 'face' < PMP * muha (Malay muka);

Iban, Salako gaway 'ceremony' < PMP *gaway (Malay upacara);

Iban sa?, Salako asà? 'one' < PMP *o sa? (Malay suatu);

Iban sida?, Salako ne? idà? 'they' < PMP *siDa (Malay m oreka);

Salako (sacral language) $u \$ i t^{11} \quad$ 'yellow' < PMP *ku $n$ ij 'curcuma' (Malay, Iban kuni y 'yellow');

Iban buuk, Salako bu?uk 'hair of head' < PMP *buh(u ə)k (Malay rambut).

An indication of the historical relevance of Malayic Dayak is the fact that many grammatical and lexical elements retained from Proto-Malayic in the seventh century Old Malay inscriptions in South Sumatra are still found in Salako and Kendayan (the 'West Malayic Dayak' dialects), whereas other Malayic languages have lost them. This is the case with some lexical items and also with the above affixes maka- and (Salako) -à?/ (Kendayan) -a?, which occur in Old Malay as maka- and - $a$ (with apparently the same meanings). The passive marker in most Malayic languages is di-. This marker apparently did not exist in old Malay (which used $n i$ - instead), whereas in Kendayan and Salako it has not developed into a passive marker, but rather into an agent marker which is prefixed to the verb in case the agent is not expressed.

Another important aspect about Malayic Dayak languages is that until recently they kept out of the main stream of Sanskrit, Arabic, Javanese, Persian and European influences which so heavily affected the lexicons of other Malayic languages.

Hudson's classification also pays attention to the fact that the Malayic Dayak languages are indigenous, whereas other Malayic languages in Borneo were introduced from Sumatra and/or Malaysia. This is important for the search of the original Malayic homeland. Three areas have been considered as a homeland: Sumatra, the Malay peninsula and Western Borneo. Kern (1889) was in favour of a homeland in the peninsular Malay area, and he rejected the possibility of a Bornean homeland. But his arguments do not hold (Adelaar 1988). The historical and linguistic evidence suggests that the Malayic settlements in the Malay peninsula are of more recent date than those in Sumatra or in Borneo (Bellwood 1993). In view of the geographical spread (in the interior), the variety (which in some cases cannot be explained as due to contact-induced change) and the sometimes conservative character of Malayic Dayak languages, some linguists 
tend to favour Borneo as the homeland of the Malayic languages (cf. Blust 1988; Adelaar 1988, 1992).

\section{Tamanic: On the Exact Nature of the Relation Between Tamanic Languages and South Sulawesi Languages}

The dialects belonging to the Tamanic subgroup are Embaloh, Kalis and Taman. They are spoken in the Hulu kapuas Regency of West Kalimantan near the head of the Kapuas River and its tributaries thereabouts. Until very recently, the information available on Tamanic dialects was restricted to wordlists. Much of the vocabulary in these lists agrees with Malay, but there are also some lexical items which are in striking agreement with South Sulawesi languages, and more particularly with Buginese. As a result, some scholars have classified Tamanic in the Malayic subgroup on the basis of lexicostatistics or exclusively shared lexical innovations (Blust 1981; Nothofer 1988), whereas other scholars have tended to classify it with South Sulawesi languages on the basis of rather impressionistic arguments (von Kessel 1850; Hudson 1978). During a one month field trip in the Embaloh area in January 1989 I was able to collect a sufficiently large corpus of data on this language to show on phonological, morpho-syntactic and lexical grounds that the Tamanic languages were more closely related to South Sulawesi languages than to the Malayic ones. Compare some of the shared lexical innovations between Embaloh and the South Sulawesi languages: ${ }^{12}$

PMP *tubuq 'body'; Proto-South Sulawesi *kale 'id.', Embaloh kale 'self; body';

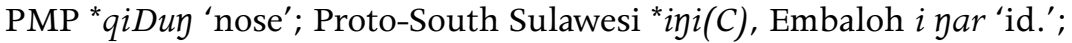

PMP *muqa, *(q)away, "paras, *daq a y 'face (of head)'; Proto-South Sulawesi *lindo, Embaloh lindo 'id.';

PMP * [nø]ipa n 'tooth'; Proto-South Sulawesi *isi, Embaloh isi 'id.';

PMP *liqa $R$ 'throat, neck'; Proto-South Sulawesi *killo $\eta$, Embaloh kalo y;

N.B.: When used verbally, Embaloh kaloy means 'to invoke' or 'to call', whereas many South Sulawesi languages also use the reflex of ${ }^{*} k i l l o y$ as the root for a verb 'to sing';

PMP *butuq, *qutiq 'penis'; Proto-South Sulawesi *laso, Embaloh laso 'id.';

PMP, Proto-South Sulawesi (no proto-form available); South Toraja ulelean, Embaloh ule?ule?an 'account, story';

PMP *waDa 'to be, exist'; Proto-South Sulawesi *dia(n), Embaloh dien 'id.';

PMP, Proto-South Sulawesi (no proto-form available); Makassarese, South Toraja taraue, Buginese tarau?, Embaloh tatara?ue? 'rainbow';

$\mathrm{PMP}^{*} t(u i) D u R$ 'sleep'; Proto-South Sulawesi *tindo, Embaloh tindo?. 
A close Tamanic-South Sulawesi relation automatically raises the question as to whether the South Sulawesi languages have their homeland in Borneo, or whether the Tamanic languages have their homeland in South Sulawesi. Furthermore, what is the exact relation between Tamanic and South Sulawesi languages: are both derived from a higher order proto-language, are the Tamanic languages a subgroup of the South Sulawesi ones, or are the South Sulawesi languages a subgroup of the Tamanic ones? Although the number of exclusively shared lexical innovations seems to be at least as high between Embaloh and Tae' (South Toraja) as between Embaloh and Buginese, there are some striking phonological agreements which compel me to assume a closer relation between Tamanic languages and Buginese than between Tamanic languages and other South Sulawesi languages. These phonological agreements are the reflex $s$ for $\mathrm{PMP}^{*} j$ in intervocalic position in both Tamanic and Buginese, whereas the other South Sulawesi have $r$, and furthermore the sporadic loss of PMP/Proto-South Sulawesi * $p$ in a set number of Tamanic and Buginese words.

Compare:

PMP ${ }^{*} j>$ Buginese and Embaloh $s$, South Sulawesi languages (minus Buginese) $r$ :

PMP *paja y 'paddy' > Proto-South Sulawesi *paze; Buginese ase, Embaloh ase (Makassarese, Mandar, South Toraja pare);

PMP *qala jaw 'day' > Proto-South Sulawesi *ilzo; Buginese a sso, Embaloh aso (Makassarese, Mandar, South Toraja allo);

PMP *ajan 'name' > Proto-South Sulawesi *azan; Buginese as $\eta$, Embaloh asan (Makassarese are $\eta$ );

PMP *laja 'burn (a wound)'; 'be hot (spices)'; Buginese lasa 'sick', Embaloh ba-lasa 'be strong' (Makassarese lara 'sour, bitter, e.g. a grapefruit');

PMP * siji 'to winnow' > Proto-South Sulawesi *sizi; Buginese sise? (Ide M. Said 1977: sise), Embaloh sese (South Toraja siri).

Loss of PMP/Proto-South Sulawesi * $p$ :

PMP *pusuq 'heart' > Proto-South Sulawesi *puso 'id.'; Buginese uso 'heart-shaped blossom of the banana-tree', Embaloh uso? 'heart-shaped tip of a banana fruit-stem';

PMP *paja y 'paddy' > Proto-South Sulawesi *paze; Buginese ase, Embaloh ase 'id.';

Proto-South Sulawesi *sa(m)po 'house' (Mills 1981:75); Buginese sao, Embaloh sao 'id.';

PMP * piliq 'choose' > Proto-South Sulawesi *pile; Buginese ile, Embaloh ile? 'id.'; PMP *punti 'banana' > PSS *punti 'id.'; Buginese utti, Embaloh unti 'id.'. 
The fact that there are many shared lexical innovations in Embaloh and Tae' (South Toraja) may be the result of the fact that Tae' speakers, who only relatively recently converted to Christianity, have in many ways been less subject to changes from outside cultures than for instance the Buginese and Makassarese, their Muslim relatives.

If, as seems to be the case, Tamanic is more closely related to Buginese than to other South Sulawesi languages, it has to be included in the South Sulawesi language group in a subgroup with Buginese (or with Buginese and Campalagian, cf. Grimes and Grimes [1987] and Sirk [1989]).

It is evident that the Tamanic-Buginese link has no connection with the Buginese migrations to the coasts of East, South and West Borneo from at least the 17th century on. The Buginese kept their identity or merged with the local Malays. Their migration to Borneo is a more recent phenomenon in comparison to a Buginese-Tamanic split, which must have preceded the Islamization of South Sulawesi. It must have happened so long ago that it allowed the Tamanic speakers to adapt and assimilate to a considerable degree to their Bornean environment, and to forget their "exo-Bornean" origin.

As to the original homeland of Tamanic, as a consequence of its apparent membership of the South Sulawesi language group it is most likely that at some point in time its speakers have left South Sulawesi and have migrated to Borneo.

\section{Land Dayak: Some Features They Have in Common With Orang Asli Languages}

According to Hudson (1978:23), it is possible that the Land Dayak languages form a subgroup with the Rejang-Baram languages, as some of the Land Dayak languages (Ribun, Pandu, Sanggau, Jongkang and Semandang) have an intervocalic $k$ in their reflexes for 'two' (cf. dukah or dukoh). This corresponds to the intervocalic stop in the word for two in some of the Rejang-Baram languages (cf. [de]gwa]). Blust (1981) classifies Land Dayak languages in one subgroup with Malayic, Sundanese, Rejang, Tamanic (Embaloh), Acehnese and Chamic on the basis of some lexical agreements (especially in the numerals). However, Land Dayak languages are morphosyntactically rather different from Malayic (and other Austronesian) languages. If their lexicons have much in common with the Malayic languages, this might just as well be the result of borrowing, as on the whole these lexicons seem to reflect different sets of sound correspondences vis-à -vis PMP.

Although it is evidently far too early to make any sort of inference about the history of Land Dayak, there are some similarities between this group and some of the Orang Asli languages ${ }^{13}$ which are striking enough to be mentioned, and which are certainly a topic for further investigation. One is the presence of a series of nasally released stops, or, as they are also called, "preploded nasals". I 
prefer the last term, because it does more justice to the actual phonetic change that has taken place. In Land Dayak, members of the preploded series (-pm, -tn and $-k \eta$, or, in some languages, $-b m,-d n,-g \eta$ ) are formed by uttering a stop without releasing the plosure, and then letting the airstream escape through the nose. In most of the Land Dayak languages, original final nasals became preploded. Compare the following examples from Sungkung, a language spoken in the West Kalimantan regencies of Sambas and Sanggau in a chain of six villages along the Sarawak border:

Proto-Land Dayak ${ }^{14}$ "yarVm 'night' > Sungkung yalopm 'id.'

Proto-Land Dayak * madVm 'rotten' > Sungkung mad $\varepsilon p m$ 'id.'

PMP *Zalan 'road, path' > Sungkung alatn 'id.'

PMP * (lnøipan 'tooth' > Sungkung jipatn 'id.'

PMP *Daqan 'branch' > Sungkung da?atn 'id.'

PMP *qiDuy 'nose' > Sungkung nukg 'id.'

Proto-Land Dayak *turay 'condylar bone' > Sungkung tulakn 'id.'

Preplosion took place in all final nasals, unless the nasal in question was historically preceded by another nasal. Compare:

PMP * [] anəm 'six' > Sungkung nəm 'id.'

Proto-Land Dayak *ram [i]n 'house' > Sungkung amin 'id.'

Proto-Land Dayak *tay an 'hand' > Sungkung ta yan 'id.'

N.B.: In the case of nuky 'nose' (see above), the preploded nasal is preceded by another nasal, but this nasal developed from a historical * $(n) D$. This * $(n) D$ became a nasal only after preplosion had taken place.

In Orang Asli ("Aslian") linguistics, preplosion is referred to as "disintegrated nasals" (Skeat and Blagden 1906:772-773) or "predenasalisation" (Benjamin 1985:14; Diffloth 1976:230). It is observed in Central Aslian languages, including Temiar and Semai. These languages also have $-j n$, as they allow palatals in word-final position. As in Land Dayak, their preploded nasals derive historically from simple nasal consonants (Skeat and Blagden 1906:773).

Some examples from Semai (taken from Diffloth 1976): rayo:jn 'jew's harp' (Diffloth 1976:243) do:ky 'house' (cf. Old Mon $\eta$ 'city, province'; Diffloth 1976:231) [gmgu:pm] 'to winnow vertically' (Diffloth 1976:236) ?ej $n$ (East Semai), ?हn

(West Semai) ' $I$ ' 
Skeat and Blagden (1906), Benjamin (1985) and Diffloth (1976) do not give exact phonotactic conditions for the occurrence of preploded nasals in Central Aslian, nor do their examples allow any conclusions on this matter. There are some Semai cases where preplosion seems to have been blocked by the occurrence of a preceding nasal (as in Land Dayak and Malayic Dayak languages).

Compare:

sma:n 'to ask' (Diffloth 1976:231)

manu:n 'small fruit sp.' (Diffloth 1976:243)

tu $\varepsilon л$ '(name of a hill)' (Diffloth 1976:242)

But there are also cases where preplosion happened in spite of a preceding nasal, and, inversely, there are cases where preplosion did not take place although there is no preceding nasal:

rayə:jn 'jew's harp' (Diffloth 1976:243)

tura:n 'the last remaining of a series, e.g. teeth'

Again, as in Land Dayak and Malayic Dayak languages, the preceding nasal in rayo:jn may eventually turn out to be a recent development from a stop or a nasal + stop cluster (as in Proto-Land Dayak *hi(n)duך 'nose' > Sungkung nuky, see above). But this is a speculative explanation, and the solution to this question involves a more thoroughgoing comparative historical study of Aslian languages than has been done so far.

Preploded nasals are not uncommon in other languages, but the change of final nasals to nasally released stops seems to be an areal feature which is typical for the languages of mainland Southeast Asia and some parts of Sumatra and Borneo. Preplosion also occurs in some Malay dialects spoken by Orang Asli (Benjamin 1985:14) and in some Malay dialects spoken by the Orang Darat and some of the Orang Utan in the Riau Archipelago (cf. Kähler 1960:36-37, 54-55). It must also have happened in Urak Lawoi', a Malayic language spoken off the Southwest coast of Thailand. In Urak Lawoi', $-p,-t$ and $-k$ must have developed from original nasals via a stage of preplosion. From Hogan's vocabulary (Hogan 1988) it appears that the phonotactic conditions for the development of Urak Lawoi' $-p,-t$ and $-k$ were rather similar to those applying to preplosion in Land Dayak languages. In Borneo, it is found in many Land Dayak languages, but some have not been affected by it, whereas reversely, some of the other Dayak languages did also develop the series. These other Dayak languages include West and East Barito languages in Central and South Kalimantan, and Malayic languages (such as Salako, Kendayan and varieties of Mualang) in West Kalimantan. The fact that preplosion occurs in Land Dayak languages as well as in Aslian languages is therefore not significant in itself. But it seems to correlate with some lexical similarities between these two language groups. Compare the 
words for 'to die' and 'to bathe' in Orang Asli languages (taken from Benjamin 1976, gloss 19 and 132):

to die to bathe

(Northern Aslian)

\begin{tabular}{|c|c|c|}
\hline Kensiu & kabis & ?ənlay \\
\hline Kintaq Bong & kabis & ?ənlay \\
\hline Jehai & kabis & ?alay \\
\hline Mendriq & kabas & ?Elay \\
\hline Bateg Deq & halot & nay \\
\hline Mintil & $k^{2} b u s^{a}$ & souc \\
\hline Bateg Nong & kabus & soc \\
\hline Che' Wong & kabus & mamuh \\
\hline \multicolumn{3}{|l|}{ (Central Aslian) } \\
\hline Semnam & kabas & mamuh \\
\hline Sabum & kabas & mamuh \\
\hline Lanoh Jengjeng & kabas & mamuh \\
\hline Lanoh Yir & kabas & mamuh \\
\hline Temiar & kabas & muh \\
\hline Semai I & ndat & mamuh \\
\hline Semai II & dat & mamuh \\
\hline Jah Hut & kabas & ma?mūh \\
\hline \multicolumn{3}{|l|}{ (Southern Aslian) } \\
\hline Mah Meri & kabas & hūm \\
\hline Semaq Beri & kabas & mahme h \\
\hline Semelai & khabas & hūm \\
\hline Temoq & kabos & mahmeh \\
\hline
\end{tabular}

Almost all Orang Asli languages exhibit kabas or a related form for 'to die', and more than half of them have mamuh or a related form for 'to bathe'. Again, the Central Aslian languages score highest in exhibiting these forms.

Forms like kabas and mamuh are also generally used in Land Dayak, where the word for 'to die' is moreover related to the words for 'to kill' and 'to sleep'. (This relationship does apparently not exist in the Orang Asli languages.) Compare:

$\begin{array}{llll} & \text { dead } & \text { kill } & \text { sleep }\end{array}$




\begin{tabular}{|c|c|c|c|c|}
\hline Bekati' & kabis & yamis & buus & mamu? \\
\hline Lara? & kabih, [-ç] & yamíh & buih & mamú \\
\hline Golek & kobis & nkabis & biis & mamuh \\
\hline Nonguh & kobis & $\eta$ komis & bis & mamúh \\
\hline Pandu & kobis & yomis & biis & mane? \\
\hline Ribun I & kobis & gkobis & $b i^{h}$ is & mandey? \\
\hline Ribun II & kobis & gkomis & biis & mandey? \\
\hline Jangkang & kobi? & komI? & bi? & manI? \\
\hline Lintang & $k($ oo $)$ bis & gkomis & biis & manI? \\
\hline Aye-aye & kubəs & ykuməs & bis & maní́? \\
\hline Sungkung & kabos & nnabos & bə?วs & mamuh \\
\hline Sekayam & kobis & gkomis & bis & Mä múhh \\
\hline
\end{tabular}

N.B. The forms mane?, mandey?, manI? and man $\ddot{i}$ ? are adaptations of Malay mandi or Malayic Dayak man(d)i?.

The fact that the Aslian languages share preplosion and a similar form for the word for 'to die' with (Land) Dayak languages was already pointed out (or hinted upon) by Skeat and Blagden (1906:773 and 435-438).

Generally speaking, similarities as the ones under discussion here may be due to (1) genetic relationship, (2) chance or (3) contact, whether in the form of cultural borrowing or a substratum. A genetic relationship will not account for the similarities, as all other evidence leaves little doubt about the classification of Land Dayak languages as Austronesian, and about the classification of Orang Asli languages as Austro-Asiatic. It would be possible to maintain that the lexical similarities are due to chance, but this seems to be a less suitable explanation for preplosion, the spread of which should be described in terms of an areal feature. If there was contact, this must have been a very long time ago, as there is, as far as I know, no evidence for it in historical times. The nature of the similarities, two rather basic vocabulary items and a phonological areal feature, suggest intimate borrowing. Allowing for the fact that our present knowledge is too scanty to draw any definite conclusion, I tend towards explaining these similarities as the result of language shift. It may have been the case that original Aslian speakers in Borneo shifted from their original language to Land Dayak, whereby few words of the original language, such as the words for 'to die' and 'to bathe' were maintained and resisted replacement by the well-attested Proto-Austronesian roots *anDuy 'to bathe' and *maCey 'to die'. It is also possible that once there was a third (unknown and now extinct) language spoken in Borneo and on the Malay Peninsula, and that its speakers in Borneo shifted to Land Dayak, while its speakers on the Malay Peninsula shifted to Aslian. Although forms like kabis and mamuh are quite common in Aslian, at this stage 
it is not clear whether they are inherited and can be attributed to Proto-Aslian. It therefore remains possible that they are innovative in both Aslian and Land Dayak.

Preplosion is found in many languages that do not belong to the same linguistic subgroup or even the same language family. Both Land Dayak and Aslian have members that have never been affected by it. Preplosion is therefore younger than the splits that led to the emergence of different Austronesian linguistic subgroups such as Malayic Dayak and Land Dayak. It is clearly not diagnostic for language classification in Southeast Asia.

\section{Post Scriptum}

1. Since the final edition of this paper in 1991, Dr Bernard Sellato brought to my attention that the Land Dayak word kobis 'to die' and its variant forms has cognates in many of the languages spoken by Punan people in Borneo.

2. Also after the final edition of this paper, O.C. Dahl published a book on the Indonesian origins of the Malagasy people (Dahl 1991).

\section{References}

Adelaar, K.A.

1988 More on Proto-Malayic. In Mohd. Thani Ahmad and Zaini Mohammed Zain (eds) Rekonstruksi dan cabang-cabang Bahasa Melayu induk, pp.5977. Siri monograf sejarah bahasa Melayu. Kuala Lumpur: Dewan Bahasa dan Pustaka.

1989 Malay influence on Malagasy: linguistic and culture-historical inferences. Oceanic Linguistics 28(1):1-46.

1991a New ideas on the early history of Malagasy. In H. Steinhauer (ed.) Papers in Austronesian linguistics No.1, pp.1-22. Pacific Linguistics Series A No. 81. Canberra: Department of Linguistics, Research School of Pacific Studies, The Australian National University.

1991b A phonological sketch of Salako. In Ray Harlow (ed.) VICAL 2 Papers from the fifth international conference on Austronesian linguistics, pp.119. Auckland: The Linguistic Society of New Zealand.

1992 Proto-Malayic: a reconstruction of its phonology and part of its morphology and lexicon. (Revised version of $1985 \mathrm{PhD}$ thesis.) Pacific Linguistics Series C No. 119. Canberra: Department of Linguistics, Research School of Pacific Studies, The Australian National University.

1994 The classification of Tamanic languages (West Kalimantan). In Tom Dutton and Darrell Tryon (eds) Language contact and change in the Austronesian world, pp.1-41. Trends in Linguistics. Studies and Monographs. Berlin: Mouton de Gruyter. 
in press The nature of Malay and Javanese linguistic borrowing in Malagasy.

(Paper presented at the 2nd Tamadun Melayu conference held in Kuala Lumpur in August 1989.)

Bellwood, Peter

1993 Cultural and biological differentiation in peninsular Malaysia: the last 10,000 years. Asian Perspectives 32:37-60.

Benjamin, Geoffrey

1976 Austroasiatic subgroupings and prehistory in the Malay peninsula. In Philip N. Jenner, Laurence C. Thompson and Stanley Starosta (eds) Austroasiatic studies Part I, pp.37-128. Honolulu: University of Hawaii Press.

1985 On pronouncing and writing Orang Asli languages: a guide for the perplexed. In Orang Asli Studies Newsletter No.4. Hanover (USA): Dartmouth College, Department of Anthropology; pp.4-16.

Blust, R.A.

1981 The reconstruction of Proto-Malayo-Javanic: an appreciation. Bijdragen tot de Taal-, Land- en Volkenkunde 137(4):456-469.

1988 The Austronesian homeland: a linguistic perspective. Asian Perspectives 26:45-67.

Cense, A.A. and E.M. Uhlenbeck

1958 Critical survey of studies on the languages of Borneo. Bibliographical series II of the Royal Institute of Languages and Cultures. The Hague: Nijhoff.

Dahl, Otto Christian

1951 Malgache et Maanyan. Une comparaison linguistique. Avhandlinger utgitt av Instituttet 3. Oslo: Egede Instituttet.

1977 La subdivision de la famille Barito et la place du Malgache. Acta Orientalia (Copenhagen) 38:77-134.

1991 Migration from Kalimantan to Madagascar. Oslo: The Institute of Comparative Research in Human Culture, Norwegian University Press.

Diffloth, Gérard

1976 Minor-syllable vocalism in Senoic languages. In Philip N. Jenner, Laurence C. Thompson and Stanley Starosta (eds) Austroasiatic studies Part I, pp.229-247. Honolulu: University of Hawaii Press.

Grimes, Charles E. and Barbara D. Grimes 
1987 Languages of South Sulawesi. Pacific Linguistics Series D No. 78. Canberra: Department of Linguistics, Research School of Pacific Studies, The Australian National University.

Hardeland, August

1858 Versuch einer Grammatik der Dajackschen Sprache. Amsterdam: Muller.

1859 Dajacksch-Deutsches Wörterbuch. Amsterdam: Muller.

Hogan, David W. (in collaboration with Stephen W. Pattemore)

1988 Urak Lawoi': basic structure and dictionary. Pacific Linguistics Series C No. 109. Canberra: Department of Linguistics, Research School of Pacific Studies, The Australian National University.

Hudson, Alfred B.

1970 A note on Selako: Malayic Dayak and Land Dayak languages in West Borneo. Sarawak Museum Journal 18:301-318.

1978 Linguistic relations among Bornean peoples with special reference to Sarawak: an interim report. In Sarawak. Linguistics and development problems, No.3, pp.1-45. Williamsburg, VA: Studies in Third World Societies.

Kähler, Hans

1960 Ethnographische und linguistische Studien über die Orang darat, Orang akit, Orang laut und Orang utan im Riau-Archipel und auf den Inseln an der Ostküste von Sumatra. Veröffentlichungen des Seminars für Indonesische und Südseesprachen der Universität Hamburg Band 2. Berlin: Dietrich Reimer.

Kern, $\mathrm{H}$.

1889 Taalkundige gegevens ter bepaling van het stamland der MaleischPolynesische volkeren. Verslagen en mededeelingen der Koninklijke Akademie van Wetenschappen, Afdeeling Letterkunde (3rd Series) 6:270287 (also published in H. Kern Verspreide Geschriften 6:105-121).

Mills, Roger F.

1975 Proto-South-Sulawesi and Proto-Austronesian phonology (2 volumes). PhD dissertation, University of Michigan, Ann Arbor (University Microfilms International 1978).

1981 Additional addenda. In R.A. Blust (ed.) Historical linguistics in Indonesia Part I. NUSA: Linguistic Studies in Indonesian and Languages in Indonesia Volume 10. Jakarta: NUSA, Universitas Atma Jaya.

Nothofer, Bernd 
1988 A discussion of two Austronesian subgroups: Proto-Malay and ProtoMalayic. In Mohd. Thani Ahmad and Zaini Mohammed Zain (eds) Rekonstruksi dan cabang-cabang Bahasa Melayu induk, pp.34-58. Siri monograf sejarah bahasa Melayu. Kuala Lumpur: Dewan Bahasa dan Pustaka.

Said, Ide M.

1977 Kamus bahasa Bugis — Indonesia. Jakarta: Pusat Pembinaan dan Pengebangan Bahasa.

Sirk, Ülo

1989 On the evidential basis for the South Sulawesi language group. In James N. Sneddon (ed.) Studies in Sulawesi languages Part I, pp.55-82. NUSA: Linguistic Studies in Indonesian and Languages in Indonesia Volume 31. Jakarta: NUSA, Universitas Atma Jaya.

Skeat, Walter William and Charles Otto Blagden

1906 Pagan races of the Malay peninsula (Vol. II). London: Macmillan.

von Kessel, O.

1850 Statistieke aanteekeningen omtrent het stroomgebied der rivier Kapuas, Wester-afdeeling van Borneo. Indisch Archief (Tijdschrift voor de Indien, Batavia) I.2:165-204.

Wurm, S.A. and Shirô Hattori

1981-3 Linguistic atlas of the Pacific area. Pacific Linguistics Series C Nos. 6667. Canberra: Department of Linguistics, Research School of Pacific Studies, The Australian National University.

\section{Notes}

${ }^{1}$ East Barito includes Malagasy.

2 Hudson himself and earlier authors used "Idahan", but this term is confusing as it turns out also to be the name of a community in Sabah using a language which does not belong to Hudson's "Idahan" subgroup. Prentice therefore proposes "Sabahan" as a less ambivalent term (Prentice, pers.comm.; see Wurm and Hattori 1981-3, note 14 on the back of map 41).

3 The Malayic languages include the Sambas, Sarawak, Brunei and Kutei dialects of Malay, and Banjarese; the Chinese languages include Hakka, Chaozhou and Hokkien (Wurm and Hattori 1981-3:map 47). There is also a Mandarin-speaking community from Shandong Province in Sabah (D.J. Prentice, pers.comm.). I am not sure if any of the descendants of Buginese immigrants in Borneo have maintained their original language. It is remarkable that none of the bibliographical sources mention the fact that the Chinese of Pontianak and surroundings are for a large part Chaozhou.

4 The first three field trips took place in the years 1986-89 and were funded by NWO, the Netherlands Organisation for Scientific Research. A fourth field trip (in 1990) was funded by the Research School of Pacific Studies, The Australian National University, Canberra.

5 A branch of the East Barito group.

6 Viz. Merina Malagasy sakarivo, Sakalava Malagasy sakaviro 'ginger' < Sanskrit ç \??||udt\\gavera 'id.' See Adelaar (1989 and in press) for the number of 35 Sanskrit loanwords, which is higher than the number (30) counted by Dahl (1951:97). 
7 A Malay or Javanese loanword, cf. Malay surat 'thing written; letter; epistle'; Javanese surat 'stripe (of colour); beam (of light); letter'.

8 But this remains to be studied (and is far less obvious than the fact that Malagasy has a Southeast Barito core and underwent Malay and Javanese influence).

${ }^{9}$ Compare the ra-prefix in kinship terms, which must be borrowed from Javanese, and some instances of prefixation of tafa- (expressing non-controlledness) and ba- (to stative verbs) which point to influence from Malay and/or Banjarese.

10 Such as, e.g., Minangkabau and Banjarese.

11 With unexplained loss of * $\mathrm{k}$.

12 Proto-South Sulawesi etyma are taken from Mills (1975 and 1981).

13 These are Austro-Asiatic (i.e. non-Austronesian) languages spoken in West Malaysia.

14 Proto-Land Dayak has not yet been reconstructed, and the etyma that I label here as such are very tentative reconstructions made on an overall impression from corresponding forms in different Land Dayak languages in my field notes and in other sources.

a i.e. a high-back unrounded vowel. 